\title{
RESPON TERHADAP MEDIA PEMBELAJARAN MELALUI E-LEARNING MOODLE SEBAGAI SUPLEMEN PEMBELAJARAN FISIKA
}

\section{RESPONSE ON LEARNING MEDIA THROUGH E-LEARNING MOODLE AS A PHYSICAL LEARNING SUPLEMENT}

\author{
Wulan Diah Puspitasari' ${ }^{1}$, Wan Jamaluddin ${ }^{2}$ \\ ${ }^{1}$ Pendidikan Fisika, Fakultas Tarbiyah dan Keguruan UIN Raden Intan Lampung \\ ${ }^{3}$ Fakultas Tarbiyah dan Keguruan UIN Raden Intan Lampung \\ E-mail : wdiahpuspitasari@yahoo.com
}

Diterima: 24 September 2018. Disetujui: 25 Oktober 2018. Dipublikasikan: 29 November 2018

\begin{abstract}
This research aims to determine the positive response of learners to the learning media that is accessed via e-leraning with moodle as a supplement of physics learning. This research was conducted in three schools in Bandar Lampung namely SMAN 13 Bandar Lampung, SMA Al-Azhar 3 Bandar Lampung and SMA Perintis 2 Bandar Lampung. Data analysis techniques used are qualitative descriptive analysis techniques and descriptive statistical analysis. The results of this study in the form of a positive assessment or response of learners to learning media accessible through e-learning with an interesting moodle used by learners.Positive responses from learners in small group testing and field trials percentage were $82 \%$ and $85 \%$ respectively. So the product is declared very good or very interesting used by learners as suplemen of physics learning.
\end{abstract}

\begin{abstract}
Abstrak: Penelitian ini bertujuan untuk mengetahui respon dari peserta didik terhadap media pembelajaran yang diakses melalui $e$-leraning dengan moodle sebagai suplemen pembelajaran fisika. Penelitian ini dilaksanakan ditiga sekolah di Bandar Lampung yaitu SMAN 13 Bandar Lampung, SMA Al-Azhar 3 Bandar Lampung dan SMA Perintis 2 Bandar Lampung. Teknik pengumpulan data menggunakan angket dengan skala Likert. Teknik analisis data yang digunakan yaitu teknik analisis deskriptif kualitatif dan analisis statistik deskriptif. Hasil penelitian ini berupa penilaian atau respon positif peserta didik terhadapmedia pembelajaran yang diakses malaluie-learning denganmoodleyang menarik digunakan oleh peserta didik. Respon positif dari peserta didik pada uji kelompok kecil dan uji coba lapangan masing-masingpersentasenya adalah $82 \%$ dan $85 \%$. Sehingga produk dinyatakan sangat baik atau sangat menarik digunakan oleh peserta didik sebagai suplemen pembelajaran fisika.
\end{abstract}

C 2018 Unit Riset dan Publikasi Ilmiah FTK UIN Raden Intan Lampung

Kata Kunci: E-Learning dengan Moodle, Pembelajaran Fisika, Respon Peserta Didik 


\section{PENDAHULUAN}

Pendidikan dapat diartikan sebagai proses yang terjadi dalam diri manusia yang berlangsung secara terus menerus (abadi) untuk memperoleh suatu perubahan tingkah laku sebagai hasil dari pengalaman individu dalam interaksi dengan lingkungan (Masykur, Nofrizal, \& Syazali, 2017; Pramesty, 2013; Rerung, Sinon, \& Widyaningsih, 2017). Sekolah sebagai suatu lembaga pendidikan formal, secara sistematis telah memiliki tujuan dalam pembelajaran.Tujuan memiliki nilai yang sangat penting di dalam pengajaran.Bahkan dapat dikatakan tujuan merupakan faktor penting dalam pembelajaran (Huda, 2013).

Agar proses pembelajaran berhasil, maka perlu sesuatu yang menarik dan mudah dimengerti oleh siswa. Siswa harus diberikan ilustrasi dan demonstrasi yang nyata untuk suatu topik tertentu. Guru dalam pembelajaran ini diharapkan dapat mengoptimalkan sarana yang tersedia untuk mencapai tujuan pembelajaran.

Selama ini sistem pengajaran khususnya di negara Indonesia masih dilakukan secara manual dengan menggunakan media yang konvensional seperti kertas (buku) dan papan tulis.Media tersebut dirasa kurang menarik karena orang mulai bosan dengan sistem pembelajaran yang dirasa sangat monoton dan kurang interaktif.Sudah seharusnya sistem pembelajaran mengalami pembaharuan dengan memanfaatkan perkembangan teknologi informasi sehingga bisa meningkatkan mutu pendidikan di Indonesia (Sukmawati, 2016).

Penggunaan media dalam pengajaran di kelas merupakan sebuah kebutuhan yang tidak dapat diabaikan. Hal ini dapat dipahami mengingat proses belajar yang dialami peserta didik tertumpu pada berbagai kegiatan menambah ilmu dan wawasan untuk bekal hidup di masa sekarang dan masa yang akan datang. Dalam hal ini, media pendidikan merupakan salah satu pendukung yang efektif dalam membantu terjadinya proses belajar (Umar, 2014). Media sendiri adalah segala sesuatu yang digunakan untuk menyalurkan pesan dari pengirim ke penerima sehingga dapat merangsang pikiran, perasaan, perhatian dan minat siswa sedemikian rupa sehingga proses belajar terjadi (Sadiman, 2012).

Teknologi merupakan bagian integral dalam setiap budaya. Makin maju suatu budaya, makin banyak dan makin canggih teknologi yang digunakan. Meskipun demikian masih banyak diantara kita yang tidak menyadari hal itu.Era globalisasi ditandai dengan terbukanya secara luashubungan antar bangsa dan antar Negara yang didukung dengantransparansi dalam informasi. Dalam kondisi transparansiinformasi yang sedemikian itu, maka kejadian atau penemuandisuatu belahan dunia akan dengan mudah diketahui dengansegera tersebar kebelahan dunia lainnya (Yuberti, 2016).

Seiring dengan perkembangan zaman dan era globalisasi yang ditandai dengan pesatnya produk dan pemanfaatan teknologi informasi, maka konsepsi penyelenggaraan pembelajaran telah bergeser pada upaya perwujudan pembelajaran modern.Keberadaan $e$ learning tidak terlepas dari keberadaan computer dan internet yang semakin maju di dunia modern ini. System pembelajaran elektronik atau e-pembelajaran (Inggris Electronic learning disingkat E-learning) adalah cara baru dalam proses belajar mengajar. E-learning merupakan dasar dan konsekuensi logis perkembangan teknologi informasi dan komunikasi (Darmawan, 
2014). E-Learning adalah salah satu evolusi, dan hampir benar-benar berasimilasi dengan lingkungan pendidikan (Shrivastava \& Jain, 2013). Pada dunia pendidikan saat ini, dikenal tiga jenis e-learning yakni edmodo, schoology dan moodle. Moodle merupakan perangkat lunak open source yang mendukung implementasi e-learning dengan berbagai fasilitas penunjang pembelajaran yang diakomodasi dalam satu portal e-learning (Putri, 2014).

Ditemukan beberapa masalah saat peneliti melakukan pra-penelitianpada tiga sekolah di Bandar Lampung yaitu SMAN 13, SMA Al-Azhar 3, dan SMA Perintis 2 Bandar Lampung yakni kurang disukainya pelajaran Fisika oleh sebagian besar peserta didik, kemudian peserta didik membutuhkan media baru yang sebelumnya belum mereka ketahui.Seharusnya pembelajaran fisika yang diperlukan saat ini adalah pembelajaran yang bersifat kreatif dan juga inovatif sehingga peserta didik dapat terlibat aktif di dalam proses belajarmengajar. Kemudian mata pelajaran fisika merupakan salah satu mata pelajaran yang dianggap sulit oleh sebagian besar peserta didik, sehingga selain dengan metode ceramah dari guru, maka peserta didik membutuhkan media e-learning guna melengkapi dan menjadi tambahan pembelajaran untuk mengoptimalkan pembelajaran fisika bagi peserta didik. Kemudian peneliti mengembangkan produk berupa media pembelajaran yang diakses melalui e-learning dengan moodle yang kemudian peneliti melakukan uji coba produk guna mengetahui respon peserta didik terhadap produk tersebut.

\section{METODE PENELITIAN}

Adapun metode penelitian yang dilakukan adalah metode deskriptif, proses penelitian yaitu dengan penyebaran angket untuk uji coba produk guna mengetahui respon peserta didik terhadap media pembelajaran yang diakses melalui $e$ learning dengan moodle sebagai suplemen pembelajaran fisika. Penyebaran angket dibagi menjadi dua tahap uji coba yakni uji kelompok kecil dan uji coba lapangan. Karakteristik sasaran penelitian adalah 45 peserta didik kelas $\mathrm{X}$ yang terdiri dari tiga sekolah di Bandar Lampung masingmasing dari SMAN 13, SMA Al-Azhar 3, dan SMA Perintis 2 Bandar Lampung. Data penelitian dikumpulkan dengan menggunakan lembar angketrespon peserta didik serta analisa data menggunakan skala Likert di analisis menggunakan statistik deskriptif.Kisi-kisi angket respon peserta didik dapat dilihat pada tabel di bawah ini:

Tabel 1. Kisi-kisi Angket Respon Peserta didik

\begin{tabular}{lll}
\hline \multicolumn{1}{c}{ Kriteria } & \multicolumn{1}{c}{ Indikator } & \multicolumn{1}{c}{$\begin{array}{c}\text { Nomor } \\
\text { Soal }\end{array}$} \\
\hline 1. Aspek & A. Komunikatif & 1 \\
Komunikasi & $\begin{array}{l}\text { B. Kreatif dan } \\
\text { Visual }\end{array}$ & 2,3 \\
& $\begin{array}{l}\text { Inovatif } \\
\text { C. Pemilihan warna, } \\
\text { gambar, video }\end{array}$ & $4,5,6,7,8$ \\
& $\begin{array}{l}\text { D. Kerapihan dan } \\
\text { Kemenarikan }\end{array}$ & 9,10 \\
& Desain & \\
\hline
\end{tabular}

1. Uji Kelompok Kecil

Uji kelompok kecil dilakukan kepada 5 peserta didik dari ketiga sekolah dengan total 15 peserta didik pada uji kelompok kecil.Sample peserta didik dipilih secara random sampling. Kemudian peneliti memperkenalkan produk berupa media pembelajaran yang diakses melalui e-learning dengan moodle kepada peserta didik yang telah dipilih. Selanjutnya, setelah peserta didik masuk ke alamat $e$ - 
learning www.forumwulan.com yang telah diberitahukan oleh peneliti, dan peneliti membagikan angket yang berisi 10 pernyataan kepada peserta didik, kemudian peserta didik mulai menilai media melalui angket respon tersebut.

\section{Uji Coba Lapangan}

Uji coba lapangan dilakukan kepada 10 peserta didik dari masingmasing sekolah dengan menyebarkan angket respon yang sama dengan angket pada uji kelompok kecil. Uji coba lapangan dilakukan guna mendapatkan hasil respon peserta didik yang lebih baik lagi dari uji kelompok kecil.

Angket respon peserta didik untuk produk media sesuai dengan konten pernyataan. Pengubahan hasil penilaian peserta didik dari huruf menjadi skor dengan ketentuan pada tabel berikut:

Tabel 2. Aturan Pemberian Skor

\begin{tabular}{ccccc}
\hline No & A1 & A2 & A3 & $\begin{array}{c}\text { Persentase } \\
\text { Total }\end{array}$ \\
\hline \multirow{2}{*}{1} & $80,8 \%$ & $82,0 \%$ & $83,6 \%$ & $\mathbf{2 4 6 \%}$ \\
& \multicolumn{2}{c}{ Rata-rata } & & $\mathbf{8 2 , 1 3 \%}$ \\
\hline
\end{tabular}

(Sartikaningrum, 2015:53)

Kemudian menggunakan statistik sebagai berikut:

1) Menghitung persentase kelayakan dari setiap aspek dengan rumus:

$$
x_{i}=\frac{\sum S}{S_{\max }} \times 100 \%
$$

(Latifah, 2015:159)
Keterangan:

$\mathrm{S}_{\max }=$ Skor maksimal

$\sum S=$ Jumlah skor

$x_{i}=$ Nilai kelayakan angket tiap aspek

2) Menghitung persentase ratarata seluruh responden :

$$
\bar{x}=\frac{\sum_{i=1}^{n} \quad x_{i}}{n}
$$

Keterangan:

$\bar{x}=$ Rata-rata akhir

$x_{i}=$ Nilai kelayakan angket tiap aspek

$\mathrm{n}$ = Banyaknya pernyataan

\section{HASIL DAN PEMBAHASAN}

Hasil dari penelitian yang dilakukan adalah persentase respon positif dari peserta didik setelah dilakukan uji kelompok kecil dan uji coba lapangan. Hasil tersebut akan dijelaskan pada tabel berikut ini.

Tabel 3. Hasil Respon Peserta Didik Pada Uji Kelompok Kecil dari Tiga Sekolah

\begin{tabular}{ll}
\hline Kategori & Skor \\
\hline SB (Sangat Baik) & 5 \\
B (Baik) & 4 \\
C (Cukup) & 3 \\
K (Kurang) & 2 \\
SK (Sangat Kurang) & 1 \\
\hline
\end{tabular}

Kode A1= SMAN 13 Bandar Lampung, A2= SMA Al-Azhar 3 Bandar Lampung dan A3= SMA Perintis 2 Bandar Lampung. Dengan demikian, dari tabel di atas diketahui informasi bahwa pada uji kelompok kecil dengan aspek komunikasi visual, SMAN 13 memperoleh persentase 80,8\% kriteria "Sangat Baik", SMA

Al-Azhar 3 memperoleh persentase $82 \%$ kriteria "Sangat Baik" dan SMA Perintis 2 Bandar Lampung memperoleh persentase 83,6\% dengan kriteria "Sangat Baik". Oleh karena itu, pada uji kelompok kecil, respon 
peserta didik memperoleh rata-rata persentase sebesar $82,13 \%$ dengan kriteria "Sangat Baik" dan dapat disimpulkan bahwa media pembelajaran yang diakses melalui e-learning dengan moodle sebagai suplemen pembelajaran fisika "Sangat Menarik" bagi peserta didik.

Tabel 4. Hasil Respon Pesrta Didik Pada Uji Coba Lapangan dari Tiga Sekolah

\begin{tabular}{ccccc}
\hline No & A1 & A2 & A3 & $\begin{array}{c}\text { Persentase } \\
\text { Total }\end{array}$ \\
\hline 1 & $91,20 \%$ & $80 \%$ & $83,0 \%$ & $\mathbf{2 4 9 , 4 0 \%}$ \\
& Rata-rata & & $\mathbf{8 3 , 1 3 \%}$ \\
\hline
\end{tabular}

Pada uji coba lapangan, kode sekolah masih sama dengan kode ketika uji kelompok kecil yakni A1= SMAN 13 Bandar Lampung, A2= SMA Al-Azhar 3 Bandar Lampung dan A3= SMA Perintis 2 Bandar Lampung. Dari tabel di atas maka diperoleh informasi bahwa respon peserta didik pada SMAN 13 memperoleh persentase 91,2\% dengan kriteria "Sangat Baik", pada SMA Al-Azhar 3 memperoleh persentase $80 \%$ dengan kriteria "Sangat Baik" dan pada SMA Perintis 2 Bandar Lampung memperoleh persentase $83 \%$ dengan kriteria "Sangat Baik". Sehingga pada uji coba lapangan, respon peserta didik dari ketiga sekolah memperoleh ratarata persentase $83,13 \%$ dengan kriteria "Sangat Baik", hasil perolehan rata-rata persentase pada uji coba lapangan ternyata mengalami kenaikan dari uji kelompok kecil. Dengan demikian, pada uji coba lapangan, respon peserta didik sangat positif, dan dapat disimpulkan bahwasannya media pembelajaran yang diakses melalui e-learning dengan moodle sebagai suplemen pembelajaran fisika "Sangat Menarik" bagi peserta didik.

\section{SIMPULAN}

Berdasarkan analisis data dan pembahasan sebelumnya maka dapat disimpulkan bahwa:

Respon positif didapat dari pemberian angket respon kepada peserta didik kelas X dari tiga sekolah. Pemberian angket respon melalui uji kelompok kecil dan uji coba lapangan Hasil respon peserta didik pada saat uji kelompok kecil sangat positif dengan persentase rata-rata sebesar $82,13 \%$ dengan kriteria "Sangat Baik" dan pada uji coba lapangan persentase rata-ratanya sebesar 83,13\% dengan kriteria "Sangat Baik" sehingga media pembelajaran yang diakses melalui e-learning dengan moodle pada pembelajaran fisika "Sangat Menarik" bagi peserta didik kelas X.

\section{DAFTAR PUSTAKA}

Darmawan, D. (2014). Pengembangan ELearning Teori dan Desain. Bandung: PT Remaja Rosdakarya.

Huda, M. (2013). Model-Model Pengajaran Dan Pembelajaran. Yogyakarta: Pustaka Pelajar.

Masykur, R., Nofrizal, \& Syazali, M. (2017). Pengembangan Media Pembelajaran Matematika dengan Macromedia Flash. Al-Jabar: Jurnal Pendidikan Matematika, 8(2).

Pramesty, R. I. (2013). Pengembangan Alat Peraga KIT Fluida Statis Sebagai Media Pembelajaran Pada Sub Materi Fluida Statis Di Kelas XI IPA SMA Negeri 1 Mojosari, Mojokerto. Jurnal Inovasi Pendidikan Fisika, 2.

Putri, N. A. (2014). Pengembangan ELearning Berbasis Schoology Pada Materi Pelajaran IPA Kelas VIII Di 
SMP Neger1 Seiriti. Journal Edutech Universitas Pendidikan Ganesha Jurusan Teknologi Pendidikan.

Rerung, N., Sinon, I. L. S., \& Widyaningsih, S. W. (2017). Penerapan Model Pembelajaran Problem Based Learning (PBL) untuk Meningkatkan Hasil Belajar Peserta Didik SMA pada Materi Usaha dan Energi. Jurnal Ilmiah Pendidikan Fisika Al-Biruni, 6(April), 47-55.

Sadiman, A. S. (2012). Media Pendidikan pengertian, pengembangan dan pemanfaatannya. Jakarta: Rajawali Pers.

Shrivastava, R., \& Jain, Y. K. (2013). Designing an Developing e-Learning Solution: Study on Moodle 2.0. In
International Journal of Machine Learning and Computing.

Sukmawati, F. (2016). Pengembangan Aplikasi Pembelajaran Biologi SMP Berbasis Android Untuk Bekal Menghadapi UAN Di SMP Islam Bakti 1 Surakarta. Jurnal Teknologi Informasi, XI.

Umar. (2014). Media Pendidikan: Peran dan Fungsinya dalam Pembelajaran. Jurnal Tarbawiyah.

Yuberti, Y. (2016). Dinamika Teknologi Pendidikan. Bandar Lampung: Lembaga Penelitian dan Pengabdian Kepada Masyarakat. 